\title{
Predation on an Egg Mass of the Terai Treefrog, Polypedates taeniatus (Anura: Rhacophoridae), by Flesh Fly Larvae (Diptera: Sarcophagidae)
}

Bitupan Boruah and Abhijit Das

Wildlife Institute of India, Chandrabani, Dehradun, Uttarakhand-248001, India (bitupan.kaz@gmail.com)

$\mathrm{T}$

The terrestrial eggs of anurans are vulnerable to attack by predators such as fly larvae (Bokermann 1957; Villa 1977, 1980; Villa and Townsend 1983; Davis and Disney 2003). Dipteran larvae in the families Psychodidae (Villa 1980), Drosophilidae, Ephydridae (Menin and Giaretta 2003), Phoridae (Vonesh 2000), Psychodidae, Syrphidae (Villa et al. 1982; Davis and Disney 2003), Tabanidae (Mohanty-Hejmadi and Dutta 1988), Calliphoridae (Yorke 1983; Lin et al. 2000; Lue and Lin 2000; Karraker 2013), and Sarcophagidae (Filadelfo et al. 2013) are known to feed on anuran eggs. However, to the best of our knowledge, the only report of predation on egg masses of Indian anurans is by Mohanty-Hejmadi and Dutta (1988). Herein we report an incidence of predation by dipteran larvae on an egg mass of the Terai Treefrog (Polypedates taeniatus).

Among the foam nesting rhacophorids, Polypedates taeniatus (Fig. 1) is restricted to the fragmented grassland patches of India and Nepal (Anders et al. 1998; Ahmed and Dutta 2000; Schleich and Kästle 2002; Das et al. 2012). Deuti et al. (2018) recently described acoustic behavior and larval development of the species in West Bengal.

During August 2018, we observed a breeding congregation of P. taeniatus in a patch of Narrowleaf Cattail (Typha angustifolia) at Bidurkuti $\left(29.28301^{\circ} \mathrm{N}, 78.10165^{\circ} \mathrm{E} ; 208 \mathrm{~m}\right.$ asl), Bijnor District, Uttar Pradesh, India. Males perched at heights ranging from the ground to approximately $1.5 \mathrm{~m}$ and
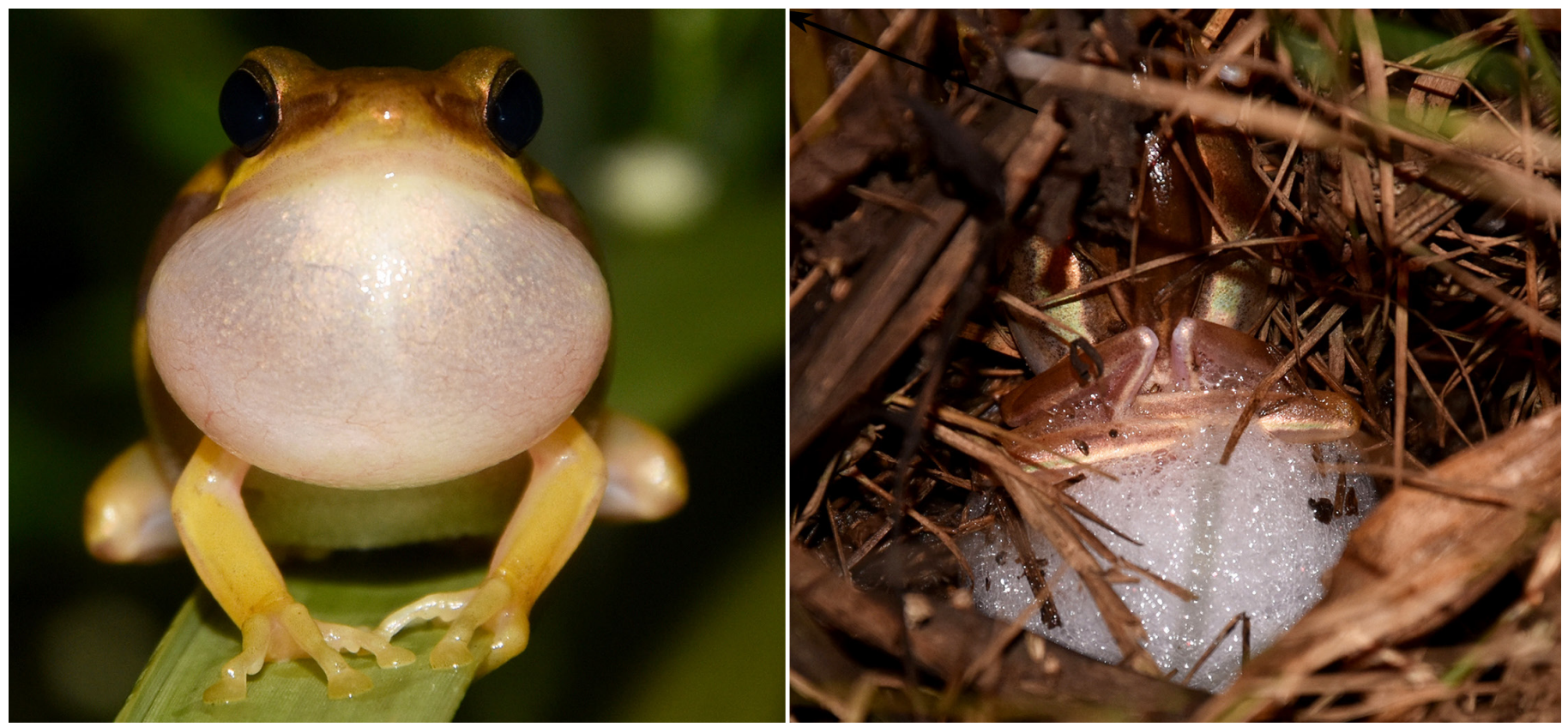

Fig. 1. Terai Treefrogs (Polypedates taeniatus): Calling male on a perch (A) and an amplecting pair constructing a foam nest on the ground (B). Photographs by Bitupan Boruah. 


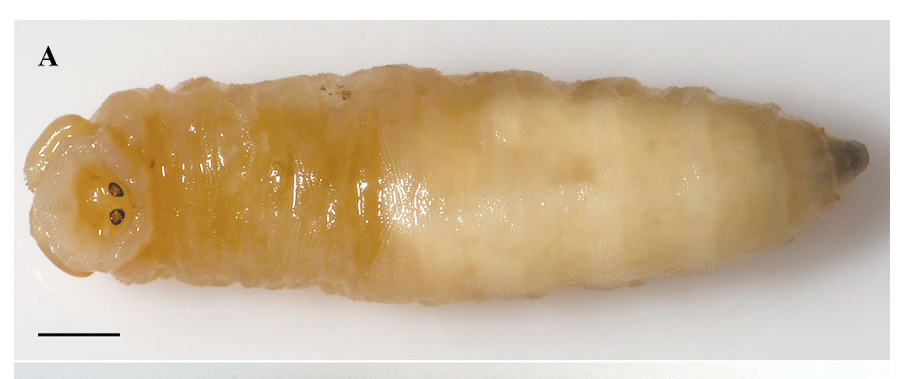

B

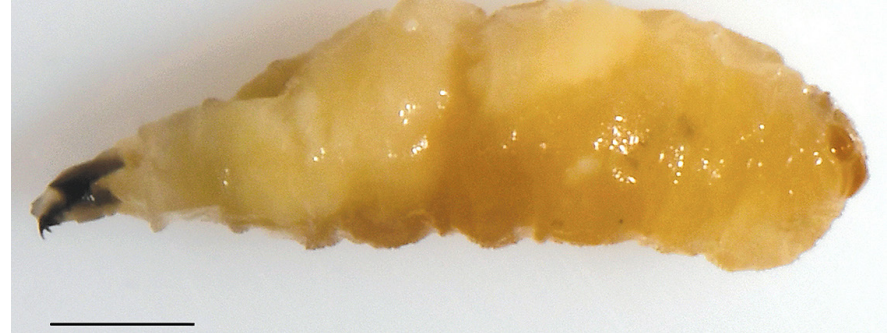

Fig. 2. Ventral (A) and lateral (B) views of flesh fly larvae (Diptera: Sarcophagidae) that had been feeding on the eggs of Terai Treefrogs (Polypedates taeniatus). Scale bars $=1 \mathrm{~mm}$. Photographs by Abhijit Das.

started calling after $1830 \mathrm{~h}$. Amplecting pairs constructed foam nests at the bases of cattails or under grass near temporary puddles, probably to minimize the risk of desiccation if exposed to direct sunlight.

On 20 August 2018, we found some cream-colored larvae in a fresh foam nest that had been constructed during the previous night. Those larvae, 4.6-10.0 $\mathrm{mm}$ (mean $=6.2 \pm 2.6$ $\mathrm{mm}, \mathrm{n}=4$ ) in length, had consumed the entire egg mass. We identified the predatory larvae (Fig. 2) as flesh flies (Diptera: Sarcophagidae) using keys in Gómez-Hoyos et al. (2012), Szpila et al. (2015), and da Silva et al. (2019). Sarcophagid larvae can be differentiated from the larvae of flies in other dipteran families by the position of the posterior spiracles in a concave spiracular field (da Silva et al. 2019). We were unable to identify these larvae to a lower taxonomic level as differentiation is possible only with adults (Mello-Patiu and Luna-Dias 2010).

Dipteran larvae have been reported to feed on the egg masses of many rhacophorid frogs, including Zhangixalus arboreus (Kusano et al. 2005), Z. aurantriventris, Z. moltrechti, Z. prasinatus (Lin et al. 2000; Lue and Lin 2000), $Z$. dulitensis, Leptomantis gauni, L. angulirostris, Chiromantis nongkhorensis, Feihyla hansenae, Polypedates leucomystax (Karraker 2013), and P. megacephalus (Lin et al. 2000; Lue and Lin 2000; Karraker 2013). Karraker (2013) observed that predation on egg masses of $P$. megacephalus by dipteran larvae (Calliphoridae) is higher in shaded areas than in unshaded areas, and suggested that the selection of oviposition site could play an important role in moderating fly-associated mortality.

\section{Acknowledgements}

We are thankful to the National Mission for Clean Ganga (NMCG), Government of India, for financial support; the Director and Dean, Wildlife Institute of India, Dehradun, for constant support; and the Forest Department of Uttar Pradesh for permission to carry out this study. We thank Arkojyoti Sarkar for help during fieldwork.

\section{Literature Cited}

Ahmed, M.F. and S.K. Dutta. 2000. First record of Polypedates taeniatus (Boulenger, 1906) from Assam, north-eastern India. Hamadryad 25: 49-50.

Anders, C.C., A. Deiner, and H.H. Schleich. 1998. First record of Polypedates taeniatus (Boulenger 1906) from Nepal (Amphibia, Anura: Rhacophoridae), pp. 73-86. In: H.H. Schleich, and W. Kastle (eds.), Contribution to the Herpetology of South Asia (Nepal, India). Veroff Fuhlrott Museum, Wuppertal, Germany.

Bokermann, W.C. 1957. Frog eggs parasitized by dipterous larvae. Herpetologica 13: 231-232.

da Silva, I.C.O., S.S. de Carvalho, K. Ceron, D.J. Santana, and L.E.R. Tavares. 2019. A case of dipteran parasitism in Trachycephalus typhonius (Anura: Hylidae), with a summary of myiasis parasitism in anurans. Phyllomedusa 18 : 283-292.

Das, A., D. Basu, L. Converse, and S.R.C. Choudhury. 2012. Herpetofauna of Katerniaghat Wildlife Sanctuary, Uttar Pradesh, India. Journal of Threatened Taxa 4: 2553-2568.

Davis, R.A. and R.H.L. Disney. 2003. Natural history and description of Aphiura breviceps Schmitz, a scuttle fly (Diptera: Phoridae) whose larvae prey on the eggs of frogs (Anura: Myobatrachidae) in Western Australia. Austral Entomology 42: 18-21.

Deuti, K., B.H.C.K. Murthy, and P.G.S. Sethy. 2018. A new distribution record of Polypedates taeniatus (Amphibia: Anura: Rhacophoridae) with notes on its breeding call and post-embryonic developmental stages. Records of Zoological Survey of India 118: 298-306.

Filadelfo, T., B.Q. Carvalho-Zimbres, P.D. Dantas, C.A. Mello-Patiu, and R. Albuquerque-Brandão. 2013. Egg clutches and predation of Phyllomedusa azurea (Anura, Hylidae) nests in a temporary pond in central Brazil. Herpetology Notes 6: 485-488.

Gómez-Hoyos, D.A., T. Suárez-Joaqui, and O.H. Marín-Gómez. 2012. Flesh fly myiasis (Diptera: Sarcophagidae) in Pristimantis thectopternus (Anura: Strabomantidae) from Colombia. Herpetology Notes 5: 27-29.

Karraker, N.E. 2013. Shading mediates the interaction between an amphibian and a predatory fly. Herpetologica 69: 257-264.

Kusano, T., A. Sakai, and S. Hatanaka. 2005. Natural egg mortality and clutch size of the Japanese treefrog, Rhacophorus arboreus (Amphibia: Rhacophoridae). Current Herpetology 24: 79-84.

Lin, S., C. Kuo, and K. Lue. 2000. Oviposition behavior and host selection of the frogfly, Caiusa coomani (Diptera: Calliphoridae). Chinese Journal of Entomology 20(4): 281-292.

Lue, K. and S. Lin. 2000. Investigation of foam nests (Rhacophoridae) infested by frogflies (Diptera) in Taiwan. Chinese Journal of Entomology 20(4): 267-280.

Mello-Patiu, C.A. and C. Luna-Dias. 2010. Myiasis in the Neotropical amphibian Hypsiboas beckeri (Anura: Hylidae) by a new species of Lepidodexia (Diptera: Sarcophagidae). Journal of Parasitology 96: 685-688.

Menin, M. and A.A. Giaretta. 2003. Predation on foam nests of leptodactyline frogs (Anura: Leptodactylidae) by larvae of Beckeriella niger (Diptera: Ephydridae). Journal of Zoology 261: 239-243.

Mohanty-Hejmadi, P. and S.K. Dutta. 1988. Life history of the common Indian tree frog, Polypedates maculatus (Gray, 1834) (Anura: Rhacophoridae). Journal of the Bombay Natural History Society 85: 512-517.

Schleich, H.H. and W. Kästle. 2002. Amphibians and Reptiles of Nepal. Biology, Systematics, Field Guide. Koeltz Scientific Books, Koenigstein, Germany.

Szpila, K., R. Richet, and T. Pape. 2015. Third instar larvae of flesh flies (Diptera: Sarcophagidae) of forensic importance - critical review of characters and key 
for European species. Parasitology research 114: 2279-2289.

Villa, J. 1977. A symbiotic relationship between frog (Amphibia, Anura, Centrolenidae) and fly larvae (Drosophilidae). Journal of Herpetology 11: 317-322.

Villa, J. 1980. Frogflies from Central and South America with notes on other organisms of the amphibian egg microhabitat. Brenesia 17: 49-68.

Villa, J. and D.S. Townsend. 1983. Viable frog eaten by phorid fly larvae. Journal of Herpetology 17: 278-281.

Villa, J., R.W. Mc Diarmid, and J.M. Gallado. 1982. Arthropod predators of leptodactylid frog foam nests. Brenesia 19: 577-589.

Vonesh, J.R. 2000. Dipteran predation on the arboreal eggs of four Hyperolius frog species in western Uganda. Copeia 2000: 560-566.

Yorke, C.D. 1983. Survival of embryos and larvae of the frog Polypedates leucomystax in Malaysia. Journal of Herpetology 17: 235-241. 